\title{
Enantioselective Total Synthesis of Bistramide A
}

\author{
Michael T. Crimmins* and Amy C. DeBaillie \\ Department of Chemistry, Venable and Kenan Laboratories of Chemistry, University of North \\ Carolina at Chapel Hill, Chapel Hill, North Carolina 27599-3290
}

\section{Abstract}

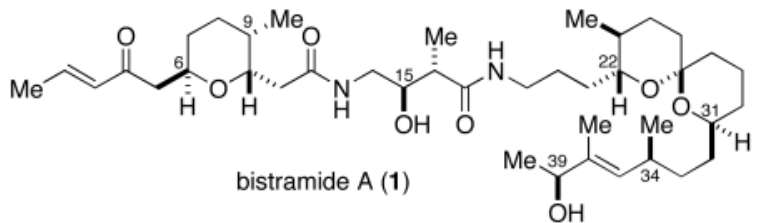

The enantioselective synthesis of bistramide A has been achieved with a longest linear sequence of eighteen steps. The synthetic strategy involves the use of a distereoselective glycolate alkylation, an aldol addition of a chlorotitanium enolate of $\mathrm{N}$-acylthiazolidinthione, and a Sharpless asymmetric epoxidation to synthesize the three key fragments.

Bistramide $\mathrm{A}^{1}(\mathbf{1})$ is a member of a new class of bioactive molecules isolated from the marine ascidian Lissoclinum bistratum. The bistramides demonstrate significant neuro- and cytotoxic properties as well as profound effects on cell cycle regulation. ${ }^{2}$ In particular, bistramide A has an $\mathrm{IC}_{50}$ of $0.03-0.32 \mu \mathrm{g} / \mathrm{mL}$ for P388/dox, B16, HT29, and NSCLC-N6 cell lines. ${ }^{3}$ Studies have shown that bistramide $\mathrm{A}$ is cell permeable, blocks sodium channels, ${ }^{4}$ and induces highly selective activation of a single protein kinase $\mathrm{C}$ (PKC) isotype $\delta .{ }^{5}$ The biological activity of bistramide $\mathrm{A}$, as well as the other bistramides, has rendered them potential candidates for the treatment of slowly evolving tumors, such as non-small cell pulmonary carcinoma. ${ }^{2}$

From the time of their original isolation, ${ }^{1 \mathrm{a}}$ the bistramides have presented a challenging stereochemical conundrum. Synthetic efforts toward the bistramides 6 were hampered by the lack of information regarding their relative and absolute configuration prior to Wipf's theoretical and synthetic studies. $6 \mathrm{~d}, 6 \mathrm{~g}$ Kozmin and coworkers ${ }^{7}$ have recently reported the first total synthesis of bistramide A, thus confirming Wipf's prediction of the stereochemical assignment of bistramide C. $6 \mathrm{~d}, 6 \mathrm{~g}$

Herein we disclose a convergent, enantioselective, total synthesis of bistramide A. At the onset of this project, the absolute configuration of bistramide A had not been established. Therefore, our goal was to devise a strategy, which would allow either enantiomer of the three key subunits to be prepared, with the added requirement that either configuration at C39 could be accessed. Hence, it was envisioned that bistramide A would derive from three fragments: pyran $\mathbf{2}$, carboxylic acid 3, and spiroketal fragment 4 (Figure 1). The pyran fragment $\mathbf{2}$ was constructed as shown in Scheme 1. Exposure of aldehyde $5^{8}$ to the chlorotitanium enolate of $N$-propionyl thiazolidinethione $6^{9}$ proceeded smoothly (87\%) with excellent diastereoselectivity (>98:2 dr). The chiral auxiliary was reductively cleaved, and the resulting aldehyde was exposed to $\mathrm{Ph}_{3} \mathrm{P}$ $=\mathrm{CHCO}_{2}$ Et to give $\alpha, \beta$-unsaturated ethyl ester $\mathbf{8}$ in $78 \%$ yield over two steps. Hydrogenation of the resulting alkene provided the saturated ethyl ester, which was converted to the lactone 
in the presence of PPTS. Reductive acylation ${ }^{10}$ of the lactone delivered acetate 9 as an inconsequential 7:1 mixture of anomers. Treatment of acetate 9 with the 2-

trimethylsilyloxy-1,3-pentadiene, ${ }^{11}$ in the presence of TMSOTf, installed the $\alpha, \beta$-unsaturated ketone moiety of pyran $10 \mathrm{in} 87 \%$ yield (9:1 dr). The TIPS ether was removed, and the resulting primary alcohol was oxidized to the acid. ${ }^{6 f}$ Esterification of the acid with hydoxysuccinimide gave pyran 2 .

The synthesis of carboxylic acid 3 began by transformation of allylic alcohol $11^{12}$ to the epoxy alcohol in $95 \%$ yield (98\% ee) via a Sharpless asymmetric epoxidation ${ }^{13}$ (Scheme 2 ).

Treatment of the epoxy alcohol with lithium dimethylcuprate yielded the 1,3-diol accompanied by the undesired 1,2-diol (6:1). The minor isomer was readily removed by treating the mixture with sodium periodate to yield 1,3-diol $\mathbf{1 2}$ in 71\% yield. Protection of diol $\mathbf{1 2}$ as the bis-silyl ether followed by oxidative cleavage of the PMB ether provided alcohol 13 in $95 \%$ yield over two steps. The azide moiety was then installed via a Mitsunobu reaction ${ }^{14}$ with diphenylphosphoryl azide, whereupon the primary TBS ether was selectively cleaved with CSA in methanol to yield alcohol 14. Oxidation ${ }^{15}$ of the primary alcohol to the carboxylic acid, followed by deprotection of the TBS ether gave the hydroxy acid in 66\% yield over two steps. The azide moiety was readily reduced to the primary amine with hydrogen and $\mathrm{Pd} / \mathrm{C}$ followed by in-situ acylation to yield the desired carboxylic acid fragment $\mathbf{3}$.

Construction of the spiroketal fragment 4 began with an asymmetric glycolate alkylation ${ }^{16}$ of the sodium enolate of imide $\mathbf{1 5}$ with allyl iodide to produce the allylated acyl oxazolidinone in $81 \%$ yield ( $>98: 2 \mathrm{dr}$; Scheme 3 ). Reductive cleavage of the auxiliary, followed by oxidation of the resulting primary alcohol under Swern ${ }^{17}$ conditions gave aldehyde 16. Subjection of aldehyde 16 to a modified Julia reaction ${ }^{18}$ with sulfone 17 gave diene 18 as a 60:40 mixture of $E: Z$ isomers. A cross-metathesis reaction of diene $\mathbf{1 8}$ with methyl acrylate provided the unsaturated methyl ester in $87 \%$ yield. Hydrogenation of the two alkenes resulted in concomitant cleavage of the benzyl ether, whereupon treatment with acid gave lactone 19 (70\% yield, 2 steps). Addition of lactone $\mathbf{1 9}$ to the lithium acetylide of alkyne $\mathbf{2 0}$ produced a ketoalcohol, which was immediately exposed to hydrogen and $\mathrm{Pd} / \mathrm{C}$ at $50 \mathrm{psi}$. As anticipated, the resulting trihydroxy ketone spontaneously cyclized to exclusively produce spiroketal $\mathbf{2 1}$ in $83 \%$ yield over two steps. Installation of the phthalimide under Mitsunobu ${ }^{14}$ conditions, followed by deprotection of the TBDPS ether gave alcohol $\mathbf{2 2}$ in $84 \%$ yield over two steps. Treatment of alcohol 22 with the Dess-Martin reagent ${ }^{19}$ provided the aldehyde, which was subjected to a Horner-Wadsworth-Emmons olefination ${ }^{20}$ with phosphonate 23 to install the $E$-olefin (C36-C37). The completed spiroketal fragment 4 was then obtained by stereoselective reduction of the resulting ketone with Corey's oxazoborolidine ${ }^{21}$ to establish the C39 stereogenic center.

With the three required fragments in hand, their assembly to bistramide A was undertaken. Cleavage of the phthalimide protecting group of $\mathbf{4}$ with methanol and methylamine gave the amine, which was immediately exposed to a PyBOP-mediated condensation with acid $\mathbf{3}$ delivering amide $\mathbf{2 4}$ in $88 \%$ yield over two steps. Removal of the Fmoc group with subsequent exposure of the unpurified amine to ester $\mathbf{2}$ provided synthetic bistramide $\mathrm{A}$ which was identical in all respects $\left({ }^{1} \mathrm{H},{ }^{13} \mathrm{C},[\alpha]_{\mathrm{D}}, \mathrm{MS}\right)$ to the natural product. The synthesis was completed with a longest linear sequence of eighteen steps.

\section{Supplementary Material}

Refer to Web version on PubMed Central for supplementary material. 


\section{Acknowledgements}

Financial support from the National Cancer Institute (CA63572) is gratefully acknowledged. Thanks also to Professors P. Wipf and S. Kozmin for helpful discussions.

\section{References}

1. (a) Gouiffes D, Moreau S, Helbecque N, Bernier JL, Henichart JP, Barbin Y, Laurent D, Verbist JF. Tetrahedron 1988;44:451. (b) Degnan BM, Hawkins CJ, Lavin MF, McCaffrey EJ, Parry DL, Watters DJ. J Med Chem 1989;32:1354. [PubMed: 2724306]

2. Biard JF, Roussakis C, Kornprobst JM, Gouiffesbarbin D, Verbist JF, Cotelle P, Foster MP, Ireland CM, Debitus C. J Nat Prod 1994;57:1336. [PubMed: 7807120]

3. Johnson WE, Watters DJ, Suniara RK, Brown G, Bunce CM. Biochem Biophys Res Commun 1999;260:80. [PubMed: 10381347]

4. Sauviat MP, Gouiffesbarbin D, Ecault E, Verbist JF. Biochim Biophys Acta 1992;1103:109. [PubMed: 1309656]

5. Frey MR, Leontieva O, Watters DJ, Black JD. Biochem Pharmacol 2001;61:1093. [PubMed: 11301042]

6. (a) Foster MP, Mayne CL, Dunkel R, Pugmire RJ, Grant DM, Kornprobst JM, Verbist JF, Biard JF, Ireland CM. J Am Chem Soc 1992;114:1110. (b) Solladie G, Bauder C, Biard JF. Tetrahedron Lett 2000;41:7747. (c) Gallagher PO, McErlean CSP, Jacobs MF, Watters DJ, Kitching W. Tetrahedron Lett 2002;43:531. (d) Wipf P, Uto Y, Yoshimura S. Chem Eur J 2002;8:1670. (e) Wipf P, Hopkins TD. Chem Commun 2005:3421. (f) Lowe JT, Panek JS. Org Lett 2005;7:3231. [PubMed: 16018628] (g) Zuber G, Goldsmith MR, Hopkins TD, Beratan DN, Wipf P. Org Lett 2005;7:5269. [PubMed: 16268555]

7. Statsuk AV, Liu D, Kozmin SA. J Am Chem Soc 2004;126:9546. [PubMed: 15291551]

8. Hamdouchi C, Sanchez-Martinez C. Synthesis 2001:833.

9. Crimmins MT, King BW, Tabet EA, Chaudhary K. J Org Chem 2001;66:894. [PubMed: 11430110]

10. Kopecky DJ, Rychnovsky SD. J Org Chem 2000;65:191. [PubMed: 10813915]

11. Pilli RA, Dias LC, Maldaner AO. J Org Chem 1995;60:717.

12. Hatakeyama S, Yoshida M, Esumi T, Iwabuchi Y, Irie H, Kawamoto T, Yamada H, Nishizawa M. Tetrahedron Lett 1997;38:7887.

13. Gao Y, Hanson RM, Klunder JM, Ko SY, Masamune H, Sharpless KB. J Am Chem Soc 1987;109:5765.

14. Mitsunobu O. Synthesis 1981:1.

15. Zhao MZ, Li J, Mano E, Song ZG, Tschaen DM, Grabowski EJJ, Reider PJ. J Org Chem 1999;64:2564.

16. Crimmins MT, Emmitte KA, Katz JD. Org Lett 2000;2:2165. [PubMed: 10891257]

17. Swern D, Mancuso AJ, Huang SL. J Org Chem 1978;43:2480.

18. Blakemore PR. J Chem Soc Perkin Trans 1 2002:2563.

19. Dess DB, Martin JC. J Am Chem Soc 1991;113:7277.

20. Paterson I, Yeung KS, Smaill JB. Synlett 1993:774.

21. Corey EJ, Helal CJ. Angew Chem Int Ed 1998;37:1987. 


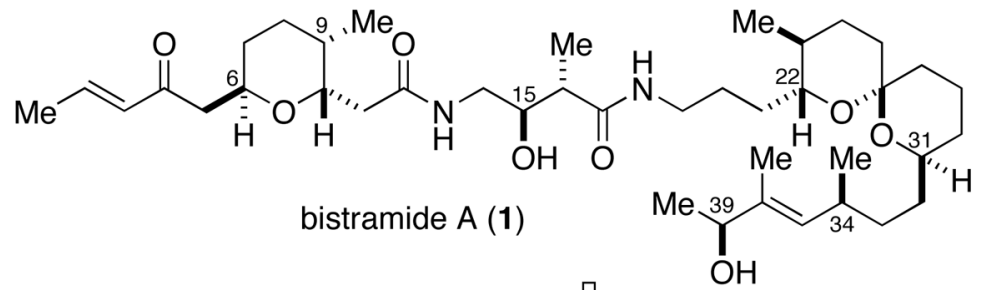

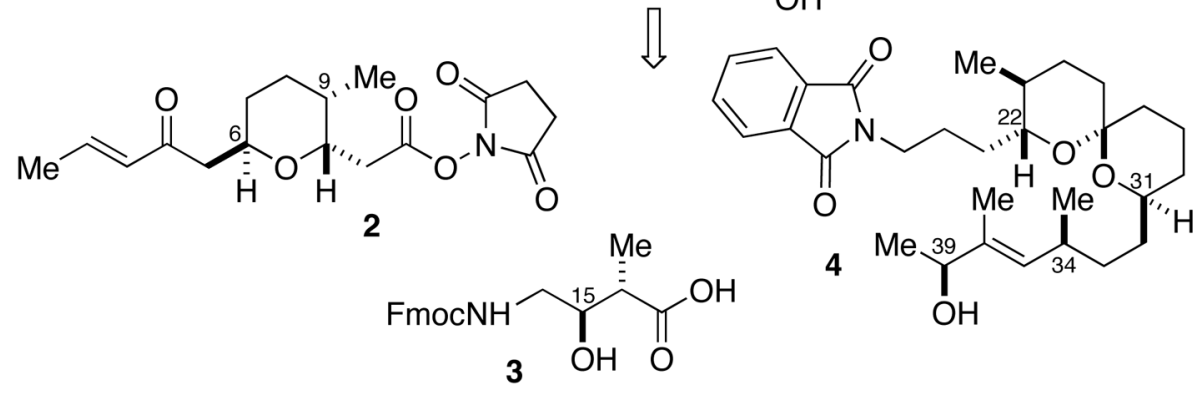

Figure 1.

Retrosynthesis of bistramide A. 


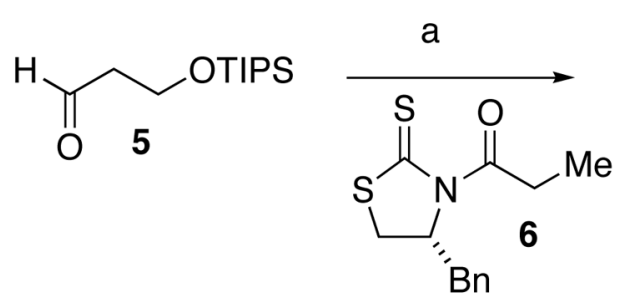<smiles>CC(C(=O)N1C(=S)SC[C@H]1Br)C(O)CC[OH+][SH2]</smiles><smiles>CCOC=CC(C)C(O)CCO[SnH3]</smiles><smiles>[TeH][TeH]</smiles><smiles>CC(=O)O[C@@H]1CC[C@@H](C)[C@H](CCO[P+](F)(F)F)O1</smiles><smiles>C1CC[Se]C1</smiles><smiles>C/C=C/C(=O)C[C@@H]1CC[C@@H](C)[C@H](CCO)O1</smiles><smiles>C#CCCCCC</smiles><smiles>[Z]C1(CC(=O)ON2C(=O)CCC2=O)O[C@@H](CC(=O)/C=C/C)CC[C@@H]1C</smiles>

Scheme 1.

Synthesis of Pyran 2

${ }^{a}$ Conditions: (a) $\mathrm{TiCl}_{4}, \mathrm{NMP},(-)$-sparteine, $\mathrm{CH}_{2} \mathrm{Cl}_{2},-78{ }^{\circ} \mathrm{C}, 6,87 \%$; (b) $i$ - $\mathrm{Bu}_{2} \mathrm{AlH}$, THF, $-78{ }^{\circ} \mathrm{C}$; (c) $\mathrm{Ph}_{3} \mathrm{P}=\mathrm{CHCO}_{2} \mathrm{Et}, \mathrm{CH}_{2} \mathrm{Cl}_{2}, 78 \%$ (2 steps); (d) $\mathrm{H}_{2}$, Raney Ni, EtOH (e) PPTS, $\mathrm{CH}_{2} \mathrm{Cl}_{2}, 40{ }^{\circ} \mathrm{C}, 81 \%$ (two steps); (f) $i$ - $\mathrm{Bu}_{2} \mathrm{AlH}$, pyridine, DMAP, $\mathrm{Ac}_{2} \mathrm{O}, \mathrm{CH}_{2} \mathrm{Cl}_{2},-78{ }^{\circ} \mathrm{C}$ to $-20{ }^{\circ} \mathrm{C}$, 96\%; (g) Et $3 \mathrm{~N}$, TMSOTf, 3-penten-2-one, $\mathrm{CH}_{2} \mathrm{Cl}_{2}, 0{ }^{\circ} \mathrm{C}$ then $-78{ }^{\circ} \mathrm{C}$, then add acetate 9, 87\%, 9:1 dr; (h) $\mathrm{H}_{2} \mathrm{SiF}_{6}, \mathrm{CH}_{3} \mathrm{CN}, 0{ }^{\circ} \mathrm{C}, 75 \%$; (i) $\mathrm{H}_{5} \mathrm{IO}_{6} / \mathrm{CrO}_{3}, \mathrm{CH}_{3} \mathrm{CN}, 77 \%$; (j) $N$ hydroxysuccinimide, $\mathrm{EDC} \cdot \mathrm{HCl}, \mathrm{CH}_{2} \mathrm{Cl}_{2}, 100 \%$. 


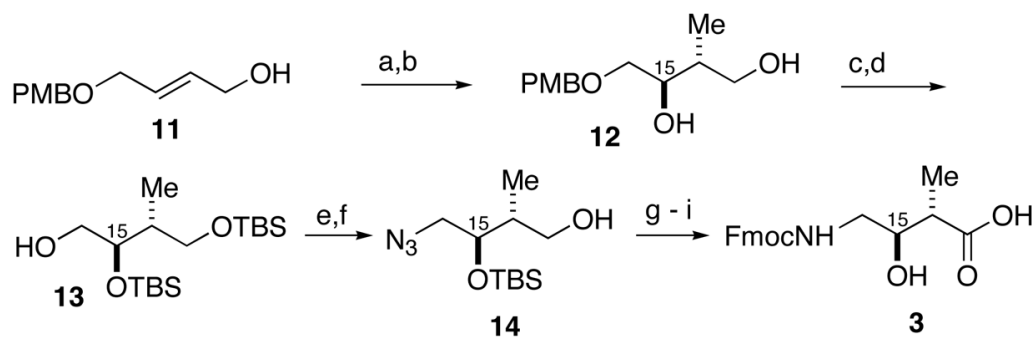

Scheme 2.

Preparation of Carboxylic Acid Fragment 3

${ }^{a}$ Conditions: (a) L-(+)-DET, $\mathrm{Ti}(\mathrm{Oi}-\mathrm{Pr})_{4}, t$-BuOOH, $\mathrm{CH}_{2} \mathrm{Cl}_{2}, 4 \AA$ sieves, $-20{ }^{\circ} \mathrm{C}, 95 \%, 98 \%$ ee; (b) $\mathrm{Me}_{2} \mathrm{CuLi}, \mathrm{Et}_{2} \mathrm{O},-50{ }^{\circ} \mathrm{C}$ to $25^{\circ} \mathrm{C}, 6: 1$ of 1,3- to 1,2-diol; $\mathrm{NaIO}_{4}, \mathrm{H}_{2} \mathrm{O}, 71 \%$; (c) TBSOTf, 2,6-lutidine, $\mathrm{CH}_{2} \mathrm{Cl}_{2}, 0^{\circ} \mathrm{C}, 97 \%$; (d) DDQ, pH 7 buffer, $\mathrm{CH}_{2} \mathrm{Cl}_{2}, 0{ }^{\circ} \mathrm{C}, 98 \%$; (e) DEAD, $\mathrm{PPh}_{3},(\mathrm{PhO})_{2} \mathrm{PON}_{3}, \mathrm{THF}, 0{ }^{\circ} \mathrm{C}, 90 \%$; (f) $\mathrm{CSA}, \mathrm{MeOH}, \mathrm{CH}_{2} \mathrm{Cl}_{2}, 0{ }^{\circ} \mathrm{C}, 85 \%$; (g) $\mathrm{NaClO}_{2}$, TEMPO, $\mathrm{CH}_{3} \mathrm{CN}, 35^{\circ} \mathrm{C}, 95 \%$; (h) HF/pyr., THF, 70\%; (i) $\mathrm{H}_{2}, \mathrm{Pd} / \mathrm{C}$, Fmoc-OSu, THF, $70 \%$. 
<smiles>C=CCC(OCc1ccccc1)C(C)=O</smiles>
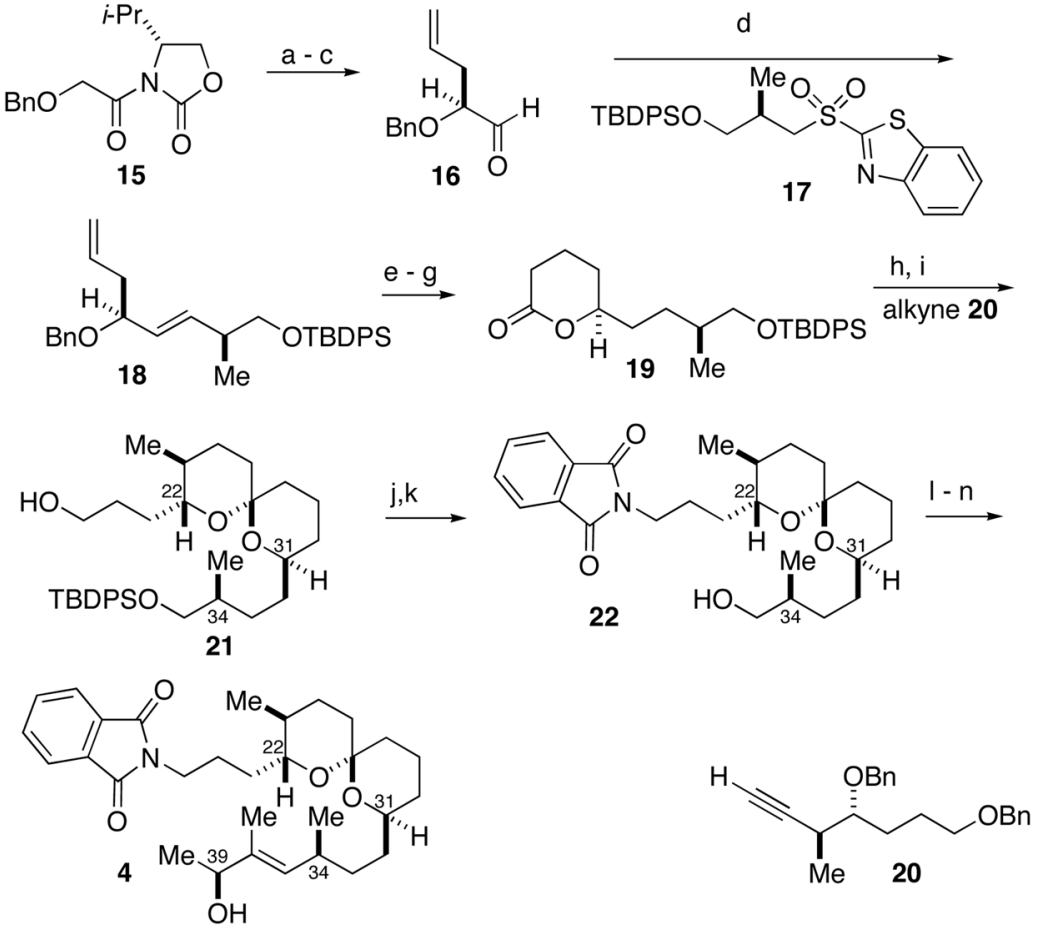

Scheme 3.

Preparation of Spiroketal Fragment 4

${ }^{a}$ Conditions: (a) NaHMDS, allyl iodide, THF, PhMe, $-78{ }^{\circ} \mathrm{C}$ to $-45{ }^{\circ} \mathrm{C}, 81 \%$; (b) $\mathrm{LiBH}_{4}$, $\mathrm{MeOH}, \mathrm{Et}_{2} \mathrm{O}, 98 \%$; (c) $\mathrm{Et}_{3} \mathrm{~N}$, DMSO, $(\mathrm{COCl})_{2}, \mathrm{CH}_{2} \mathrm{Cl}_{2},-78^{\circ} \mathrm{C}$ to $25^{\circ} \mathrm{C}, 98 \%$; (d) LiHMDS, THF, sulfone 17, then aldehyde $16,-78{ }^{\circ} \mathrm{C}$ to $-20{ }^{\circ} \mathrm{C}, 87 \%$; (e) $\mathrm{Cl}_{2}\left(\mathrm{Cy}_{3} \mathrm{P}\right)(\mathrm{IMes}) \mathrm{Ru}=\mathrm{CHPh}$, methyl acrylate, $\mathrm{CH}_{2} \mathrm{Cl}_{2}, 40{ }^{\circ} \mathrm{C}, 87 \%$; (f) $\mathrm{H}_{2}$, Pd/C, EtOAc; (g) $p$-TSA, benzene, $80{ }^{\circ} \mathrm{C}, 70 \%$ (two steps); (h) alkyne 20, $n$-BuLi, $-78^{\circ} \mathrm{C}$, then lactone 19; (i) $\mathrm{H}_{2}, \mathrm{Pd} / \mathrm{C}, \mathrm{MeOH}, \mathrm{EtOAc}, 83 \%$ (2 steps); (j) $\mathrm{PPh}_{3}$, DEAD, phthalimide, THF, $0{ }^{\circ} \mathrm{C}$; (k) HF/pyr., THF, 84\% (2 steps); (1) DessMartin periodinane, $\mathrm{CH}_{2} \mathrm{Cl}_{2}$, pyr., $92 \%$; (m) $\mathrm{Ba}(\mathrm{OH})_{2}$, THF, $\mathrm{MeCOCH}(\mathrm{Me}) \mathrm{P}(\mathrm{O})(\mathrm{OEt})_{2}(\mathbf{2 3})$, $58 \%$; (n) $(R)$-CBS, catecholborane, toluene, $-78{ }^{\circ} \mathrm{C}, 65 \%,>98: 2 \mathrm{dr}$. 

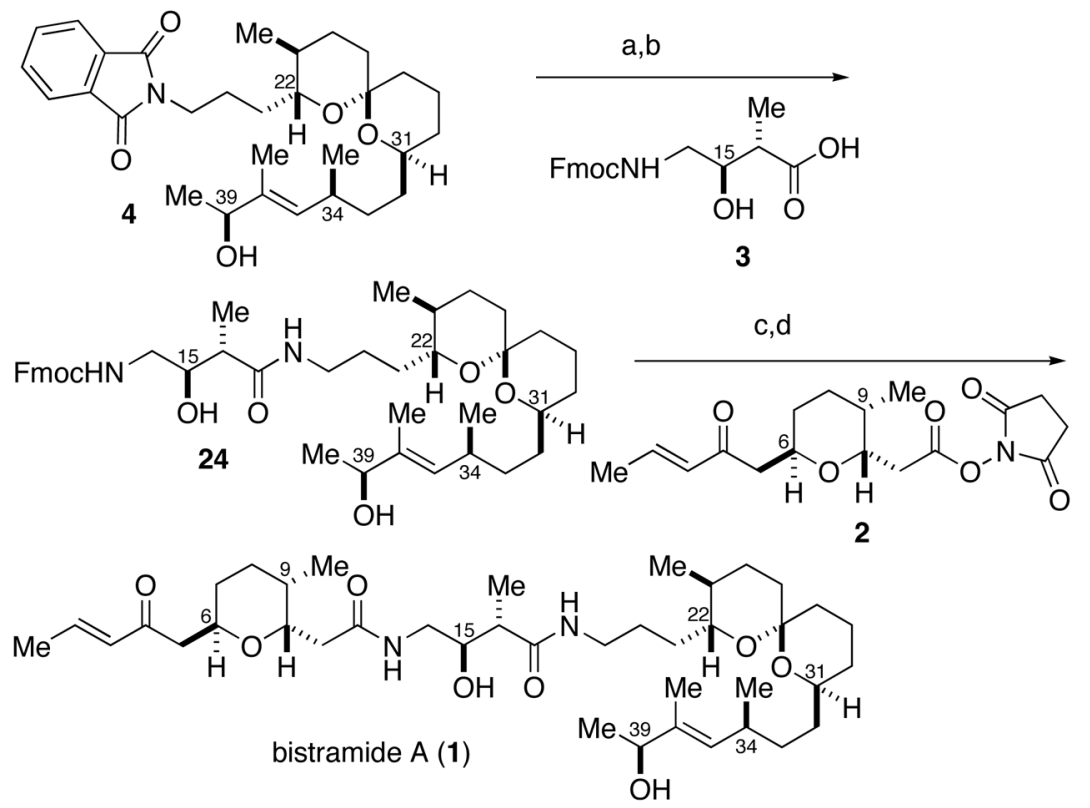

Scheme 4.

Synthesis of Bistramide A

${ }^{a}$ Conditions: (a) $\mathrm{MeOH}, \mathrm{MeNH}_{2}, 65^{\circ} \mathrm{C}$; (b) PyBOP, 3, DIEA, DMF $88 \%$ (2 steps); (c) $\mathrm{Et}_{2} \mathrm{NH}, \mathrm{DMF}$; (d) 2, DMF 82\% (2 steps). 